\title{
The Use of Organizational Capabilities to Increase Customer Value
}

\author{
Silvia Martelo Landroguez \\ Carmen Barroso Castro \\ Gabriel Cepeda Carrión
}

University of Seville

July 2012

This research were carried out thanks to a research programme supported by the Spanish Ministry of Education (REF: ECO2011 -28 641-C02-01).

Comments by Wagner Kamakura and Dusya Vera to an earlier draft were helpful in revising this paper. The authors alone are responsible for all limitations and errors that may relate to the study and the paper.

Send correspondence to Silvia Martelo Landroguez, Department of Management and Marketing, University of Seville, Ramón y Cajal, 1, Seville, Spain [smartelo@us.es] +34954554428; Carmen Barroso Castro, Department of Management and Marketing, University of Seville, Ramón y Cajal, 1, Seville, Spain, [barroso@us.es] +34954557521; Gabriel Cepeda Carrión, Department of Management and Marketing, University of Seville, Ramón y Cajal, 1, Seville, Spain [gabi@us.es]+34954554433. 


\begin{abstract}
The customer role for the firm's management has been increasing in the last twenty years.. A firm's organizational capabilities, both internally and externally oriented, are essential for increasing customer value creation and the focus of this paper is on "market orientation", "knowledge management" and "customer relationship management". The aim of the study is also to identify possible combinations of these organizational capabilities and to propose and analyze a sequence that will allow the creation of superior customer value. Thus, the authors test how a firm should recombine its existing capabilities when customer demands superior value in the Spanish banking industry. The results show that a specific combination of organizational capabilities can increase the customer value.
\end{abstract}

Keywords: Dynamic capabilities, knowledge management, market orientation, customer value. 


\section{INTRODUCTION}

In the last decades, a firm's attitude towards the customer is becoming crucial. The role of the customer has changed from that of a mere consumer to one of consumer, co-operator, co-producer, co-creator of value and co-developer of knowledge and competencies (Wang, Lo, Chi, \& Yang, 2004). Furthermore, in the complex competitive environment in which firms operate, the customer now expects superior value (Sánchez, Iniesta, \& Holbrook, 2009). More and more firms therefore see customer value as a key factor when seeking new ways to attain and maintain a competitive advantage (Woodruff, 1997).

A firm's organizational capabilities are of paramount importance for increasing customer value creation. Managers should therefore focus on developing the capabilities that view the customer as a key component, in order to create maximum customer value. The focus of this paper is on three capabilities: "market orientation" (MO), "knowledge management" $(\mathrm{KM})$ and "customer relationship management" (CRM). Of interest is that although many people consider these capabilities as being internal in nature because companies develop them all, the growth of a relationship with the customer and the capabilities associated with market orientation depends on considerable external contact.

A review of the existing literature reveals a clear link between each of these three capabilities and customer value. The primary aim of market oriented firms, firms that manage their knowledge, or those that manage customer relationships, is to offer superior customer value. However, no single or occasional influence is important, but instead, the effect of the three capabilities has to be global and sustainable (i.e., permanent). According to Sirmon, Hitt, and Ireland (2007), merely possessing valuable 
and rare resources and capabilities does not guarantee the development of competitive advantage or the creation of value; firms must be able to manage them effectively. A firm can therefore create value by recombining its existing resources and capabilities (Morrow, Sirmon, Hitt, \& Holcomb, 2007). A firm should be able to reconfigure its organizational capabilities in order to continually create value, which is where dynamic capabilities (DC) come into play.

Although Liyun, Keyi, Xiaoshu, and Fangfang (2008) suggest a possible relationship between these three organizational capabilities, the authors of this paper are not convinced by this theoretical justification, since the published paper only discusses the possible influence of the relationship on business performance. The authors of this study found no examples in the literature that examine the relationship between the three proposed organizational capabilities, nor any that consider their impact on customer value. This study addresses the gap in the literature by proposing that a recombination of the three capabilities (MO, KM and CRM) increases customer value and aims to identify how these three capabilities influence customer value. The authors also propose that such a recombination can constitute a dynamic capability (viewed as a "black box") which allows a firm to maintain its competitive advantage. The specific research question is: If the customer demands superior value, how should a firm recombine its existing capabilities to be able to offer this superior value?

In short, the aim of this paper is to contribute to the strategic management literature by determining the relationship between the three capabilities (MO, KM and CRM) and the potential effects of this relationship, in order to see what happens inside the proposed "black box" for increasing customer value. The authors attempt to identify possible combinations of the three organizational capabilities and propose and analyze a 
sequence for creating superior customer value (Barreto, 2010; Eisenhardt \& Martin, 2000; Newey \& Zahra, 2009; Teece, Pisano, \& Shuen, 1997; Wang \& Ahmed, 2007; Zahra, Sapienza, \& Davidsson, 2006; Zott, 2003).

The paper begins with an explanation of the theoretical context, followed by a presentation of the study model and the positing of a number of hypotheses. The third section contains a description of the principal aspects of the methodology, such as the research context, measures, data collection and analysis technique (structural equation modeling (SEM)); a discussion of the results and implications of the study follows; and the paper concludes with the limitations of the study and possible areas of further research.

\section{THEORETICAL BACKGROUND}

The resource-based view (RBV) regards the firm as a bundle of resources and capabilities, and assumes a heterogeneous distribution of these resources and capabilities across firms that persists over time (Ambrosini \& Bowman, 2009; Amit \& Schoemaker, 1993; Barney, 1991; Barney, Ketchen, \& Wright, 2011; Maritan \& Peteraf, 2011; Wang \& Ahmed, 2007). Taking this assumption, academics suggest that when firms have resources and capabilities which are valuable, rare, inimitable and nonsubstitutable (VRIN), they can use them to implement value creation strategies that can lead to a sustainable competitive advantage (Barney, 1991; Peteraf \& Barney, 2003). Thus, a firm's resources and capabilities can lead to value creation through the development of a competitive advantage (Ireland, Hitt, \& Sirmon, 2003). Nevertheless, merely possessing these resources and capabilities does not guarantee the creation of value or the development of a competitive advantage (Priem \& Butler, 2001). 
Firms must therefore accumulate, combine and exploit their resources to create value (Sirmon \& Hitt, 2003). However, very few studies examine how firms/managers should transform their resources to create value (Priem \& Butler, 2001).

One of the few studies that analyzes the processes that take place in the development of capabilities to create customer value (Sirmon et al., 2007) identifies the role of the capabilities configuration design (the so-called mobilizing process), which requires an understanding of the markets and customer needs; the integration of capabilities to generate new configurations (the coordinating process); and the use of the configuration of the capabilities (the deploying process).

The highly dynamic business environment of the 1990s challenged the original assumptions of the RBV, which are static and do not take account of market dynamism (Eisenhardt \& Martin, 2000; Priem \& Butler, 2001). Consequently, Teece et al. (1997) posited the dynamic capabilities view (DCV) to address that gap. As a result, the current view is that the DCV is an extension of the RBV (Ambrosini \& Bowman, 2009; Ambrosini, Bowman, \& Collier, 2009; Barreto, 2010; Easterby-Smith \& Prieto, 2008). The DCV focuses on the firm's ability to face rapidly changing environments, to create and renew resources, and change the resources mix (Ambrosini \& Bowman, 2009; Teece et al., 1997).

This concept suggests therefore that firms do not only compete because of their ability to exploit their existing resources and capabilities but also because of their ability to renew and develop them (Teece et al., 1997). After a review of some of the numerous definitions of DC (Barreto, 2010; Eisenhardt \& Martin, 2000; Newey \& Zahra, 2009; Teece et al., 1997; Wang \& Ahmed, 2007; Winter, 2003; Zott, 2003; among others), the 
definition of DC in this paper is “the firm's capacity to reconfigure its operational capabilities".

Firms are aware of their customers' demand for superior value and they need to understand how to recombine their existing capabilities to be able to satisfy their customers' demands. The classification of this paper therefore comes within the DCV.

\section{Market orientation (MO)}

By defining capabilities as "a firm's capacity to use its resources in order to achieve a desired end", and resources as "stocks of available factors owned or controlled by a firm" (Amit \& Schoemaker, 1993); the most appropriate description of MO is as an organizational capability.

The definition of MO as a capability refers to a firm's superior ability to understand and satisfy its customers (Day, 1990). Day (1994) points out that MO constitutes a distinctive capability which systematically gathers, interprets and uses market information (Chang \& Chen, 1998). According to Kaur and Gupta (2010), in order to build an MO capability, managers need to stimulate market oriented behaviors, by designing market oriented processes.

Grewal and Tansuhaj (2001) identify MO as an important organizational capability for managing economic crises. Similarly, Tuominen, Rajala, and Möller (2004) view MO as a capability that enables firms to carry out activities that process and respond to market information.

MO is therefore one of the operational capabilities proposed in this study, and the definitions of operational capabilities clearly regard MO as such (Ambrosini et al., 2009; Wang \& Ahmed, 2007; Winter, 2003; Zahra et al., 2006). Most definitions of 
operational capabilities in the literature refer to a set of abilities and resources that firms devote to resolving a problem or achieving a result, which then enables them to earn a living in the present. Without these capabilities, the firm could not collect from its customers the revenue that allows managers to buy more inputs and so repeat the whole process (Winter, 2003).

Therefore, following a review of some of the numerous definitions of MO (Day, 1994; Kaur \& Gupta, 2010; Kohli \& Jaworski, 1990; Narver \& Slater, 1990; Slater \& Narver, 1995; Woodruff, 1997; among others), the authors define market orientation as an organizational capability that allows "the generation of appropriate market information pertaining to customers' current and future needs; the integration and dissemination of this information across departments; and the coordinated design and execution of the firm's strategic response to market opportunities".

\section{Knowledge management (KM)}

Many researchers recognize that KM is an organizational capability (Chen \& Huang, 2009; Gold, Malhotra, \& Segars, 2001).

A great deal of knowledge belongs to individual people, which hinders the dissemination of this knowledge throughout the firm (Grant, 1996). Firms still require the capability to manage the knowledge to which they have access, to ensure its appropriate use (Chen \& Huang, 2009).

Gold et al. (2001) understand the KM capability as the processes that a firm requires in order to develop and use its knowledge. Li, Huang, and Tsai (2009) and Tsai and $\mathrm{Li}$ (2007) refer to $\mathrm{KM}$ as the capability to create and use knowledge in order to build a sustainable competitive advantage, given that knowledge is a VRIN resource. 
For the same reasons put forward that classify MO as an organizational capability, the authors also categorize KM an organizational and an operational capability.

The assumption that $\mathrm{KM}$ is an organizational capability implies that firms need to possess a set of resources in order to create, use and share knowledge. Therefore, after a review of some of the many definitions of KM (Chou, Chang, Cheng, \& Tsai, 2007; Lin, 2007; among others), the authors define KM as an organizational capability that allows "the integration of people, technologies, processes and strategy within the firm to create, use and share knowledge".

\section{Customer relationship management (CRM)}

The many descriptions, definitions and conceptualizations of CRM reflect the variety of viewpoints among authors. The most complete classification of these viewpoints is by Zablah, Bellenger, and Johnston (2004) and one of the five perspectives they identify describes CRM as a capability. Some authors recognize CRM as a capability emphasizing the fact that firms need to invest in the development and attainment of a set of resources that enables them to modify their behavior towards their customers. On the other hand, some authors, as Peppers and Rogers (2004) and Rogers (2005), view CRM as a business philosophy or orientation. Following these authors, CRM is mostly about transforming the business into a customer-focused enterprise. Because of that, this view considers that CRM concept integrates OM. In this paper, in order to clarify and discriminate the effect of organizational capabilities on customer value, the authors consider CRM as a capability independent of the other two.

Boulding, Staelin, Ehret, and Johnston (2005) refer to CRM as the capability that the firm requires to develop and maintain good customer relationships. Other authors 
such as Yim, Anderson, and Swaminathan (2004) and Kim and Kim (2009), also define CRM as a capability.

The authors of this study also view CRM as an organizational capability. After reviewing some of the definitions (Kim \& Kim, 2009; Reinartz, Krafft, \& Hoyer, 2004; Sin, Tse, \& Yim, 2005; Zablah et al., 2004; among others), the authors of this paper define CRM as an organizational capability that enables a "firm's activities that aim to enhance the creation and maintenance of long-term relationships with their customers in order to obtain customer loyalty and satisfaction".

The general view is that CRM, like MO and KM, is an operational capability, giving firms the opportunity to earn a living in the present, through the transformation and use of their existing resources.

\section{Customer value creation}

Practitioners have long recognized that the essential elements of a firm's business strategy consist of being able to understand what customers value within a particular offering; creating value for them; and then managing this value over time (Porter, 1985; Slater \& Narver, 1998). Being able to identify what customers want from a product or service also helps a firm to formulate its value proposition. Porter (1985) notes that a firm's competitive advantage stems from its ability to create value for customers that exceeds the cost of creating that value (DeSarbo, Jedidi, \& Sinha, 2001).

"Customer value" emerged in the 1990s as a topic of growing interest for firms and academics and practitioners now view the concept as one of the most significant factors for a firm's success (Parasuraman, 1997; Woodruff, 1997). Many authors identify customer value as an important source of competitive advantage (Mizik \& 
Jacobson, 2003; Spiteri \& Dion, 2004; Woodruff, 1997) and as the foundation of a firm's marketing activities (Holbrook, 1996). Others authors consider customer value to be a critical strategic tool for attracting and retaining customers (Lee \& Overby, 2004; Sánchez \& Iniesta, 2006; Wang et al., 2004) and as an indicator of repurchase intentions (Parasuraman \& Grewal, 2000).

Over the last few decades, firms have found themselves in a new and complex competitive environment, in which customers increasingly seek customer value (Sánchez et al., 2009). The literature discusses at some length this growing interest in the creation and provision of superior customer value (Smith \& Colgate, 2007; Wang et al., 2004) by partially replacing more limited concepts such as quality (Cronin, Brady, \& Hult, 2000) or satisfaction (Woodruff, 1997).

The RBV identifies value creation as a significant organizational capability that can contribute to a firm's success and as an important source of competitive advantage (Mizik \& Jacobson, 2003; Mocciaro \& Battista, 2005; Spiteri \& Dion, 2004). Customer value creation results from a firm's ability to use its resources to achieve a desired aim (Amit \& Schoemaker, 1993) and this study demonstrates that a firm's ability to create superior customer value will depend on the recombination of its resources and capabilities.

\section{COMBINATIONS OF CAPABILITIES AND CUSTOMER VALUE CREATION}

Many authors link MO to the objective of creating customer value (Kaur \& Gupta, 2010; Lafferty \& Hult, 2001; Narver \& Slater, 1990; Slater \& Narver, 1995) and the literature discusses the relationship between $\mathrm{KM}$ and customer value (Gebert, Geib, Kolbe, \& Brenner, 2003; Kaplan \& Norton, 2004). In fact, many authors describe KM 
as a bundle of processes that firms need to enable them to use what they know in order to create value for their customers (Vorakulpipat \& Rezgui, 2008). Many authors also posit value creation as a key characteristic of CRM (Boulding et al., 2005; Payne \& Frow, 2005; ).

The literature argues that MO, KM and CRM foster the creation of superior customer value (Martelo, Barroso, \& Cepeda, 2011) and the authors of this study can therefore reasonably propose that a particular combination of the three organizational capabilities might constitute a dynamic capability (DC), whose output would be an improvement in the customer value creation capability. But the question is, what form should this recombination take?

The authors of this paper have not found any studies that examine the relationships between the three capabilities. The research model in this study states that a recombination of the three organizational capabilities (MO, KM and CRM) has a sequential influence on a firm's capability to create superior customer value.

Although customer value is a very common topic in the literature, very few studies indicate the need to analyze the organizational capabilities that a firm needs to create customer value (Martelo et al., 2011). According to Mocciaro and Battista (2005), value creation refers to the firm's role within its economic system, and the firm's capacity to perceive and implement new combinations of resources (Schumpeter, 1934). Such new combinations allow the firm to develop new competences and new knowledge to increase the efficient use of the resources that are available to it within the economic system. 
The proposal in this paper is that by recombining the existing MO, KM and CRM, a firm seeks to satisfy its customers' desires and needs by creating value for them. In fact, Porter (1985) argues that a firm creates value by developing/inventing new ways of making things, using new methods, new technologies and/or new materials.

However, this paper goes one step further, and looks inside the "black box" that constitutes the recombination of the three capabilities. The authors of this paper attempt to identify the ideal relationship between MO, KM and CRM, that would enable the firm to create customer value.

A review of the previous literature shows different possible relationships between these variables. After a comprehensive analysis of these possible relationships, the authors propose the following model:

\section{Figure 1 here.}

Figure 1 shows that $\mathrm{KM}$ is the first capability in the sequence and the authors propose that $\mathrm{KM}$ has a positive influence over MO. The reader might think that an obvious relationship exists between these two variables if they consider MO to be specific knowledge. While Kohli and Jaworski (1990) defend the concept of "marketing intelligence", which they associate simply with a level of knowledge, other contemporary authors, such as Narver and Slater (1990), introduce a broader concept, which includes the idea of the culture, attitude or way of doing things, that go beyond the firm's marketing function. This paper distinguishes between MO and KM, and the view is that $\mathrm{KM}$ is the operational management of knowledge; that is, a tool to manipulate a firm's knowledge and to articulate the processes that use this resource. Conversely, $\mathrm{MO}$ has a more strategic function in this study, as a concept that 
encompasses the attitude and philosophy or tendency for a firm to be in contact with and to pay attention to the market.

Firms should first prepare themselves in order to manage knowledge, which requires them to foster an appropriate culture among their employees and incorporate the technology and processes they require to manage knowledge. Once the appropriate $\mathrm{KM}$ infrastructure is in place, the firm should focus on the market and capture information about customers' needs, and then disseminate and react to this information. The authors propose that firms need first to examine their own internal structure, to ensure that they have the appropriate KM infrastructure in place before they look outwards for the information they require about their customers. Firms can create superior customer value once they begin to manage this information internally. In fact, Kaur and Gupta (2010) suggest that firms can use KM as an effective way of generating and disseminating market information.

The authors justify this relationship by referring to the one that exists between organizational learning and MO. Following Huber (1991), the definition of organizational learning in this paper is the development of new knowledge and ideas with the potential of influencing behavior. The relationship between organizational learning and MO is a topic of considerable interest to academics (Baker \& Sinkula, 1999; Hunt \& Morgan, 1995; Sinkula, Baker, \& Noordewier, 1997; Slater \& Narver, 1995). Slater and Narver (1995) state that without organizational learning, MO can have no positive effects on business performance. Consequently, MO alone is insufficient for firms to learn. Success depends not only on the actions of acquisition, dissemination and reaction to market information, but also on continual improvements in information processing. 
The next capability in the sequence is MO, followed by CRM. MO positively influences CRM by encouraging the establishment of a series of processes and capabilities within the firm which lead to an understanding of the customers' needs and desires, enabling firms to more effectively manage relationships with their customers (Boulding et al., 2005; Javalgi, Martin, \& Young, 2006). These two capabilities have some clear similarities: both are oriented towards the satisfaction of customers' desires and preferences; both involve the whole firm, not just the marketing department; and both take a long-term view. Using the study by Barroso and Martín (1999), the authors propose that CRM represents a way of being market oriented, with the emphasis on customer orientation. Firms attempt to establish and exploit long-term relationships in order to build customer loyalty and to make a positive impact on their economic performance.

In summary, a firm with KM possesses a key capability for the creation of customer value. To manage knowledge effectively, firms must put in place an organizational culture that encourages knowledge management. This culture is the MO, and in order to make full use of both the market oriented culture and external knowledge, the firm must have a maintaining capability. This last capability is CRM.

A relationship might also exist between KM and CRM. Although current opinion generally treats these concepts as separate research topics, Gebert et al. (2003) show that the integration of CRM and $\mathrm{KM}$ at the process level benefits both management approaches. On the one hand, customer oriented KM focuses on the type of knowledge that is most valuable to the firm -customer knowledge- but on the other hand, knowledge oriented CRM can use a conceptual framework for the cost-effective management of the knowledge a firm requires for high quality relationships (Gebert et 
al., 2003). Although arguments have been put forward that support this relationship, the opinion of the authors is that KM influences CRM through MO. The model does not therefore require a third relationship, which might affect the previous two.

The authors therefore propose the following hypotheses:

Hypothesis 1 $a$ : Knowledge management (KM) positively influences market orientation $(\mathrm{MO})$.

Hypothesis 1 $b:$ Market orientation (MO) positively influences customer relationship management (CRM).

Hypothesis $1_{c}$ : Customer relationship management (CRM) positively influences customer value creation.

\section{METHODOLOGY}

\section{Data collection}

The context for the research hypotheses is the Spanish banking industry, including retail and commercial banks (bancos) and saving banks (caja de ahorros) which serve the general public; representing around 18 percent of the national GDP.

This industry sector is suitable because banking simultaneously demonstrates the four organizational capabilities within the model (MO, KM, CRM and customer value creation). Banking is a very knowledge-intensive industry and therefore an appropriate one in which to identify, analyze and evaluate these capabilities. The increasingly intense competition within the financial service industry is forcing banks to recognize the need to seek new ways of creating customer value. In addition to the competitiveness of the industry, the relative intangibility of their products/services 
creates the need to capture and retain customers by offering them something extra, through MO, KM and CRM. These aspects demonstrate that the industry is appropriate for this study.

The crisis in the financial services industry is highly significant; both now and at the time the study took place. The effect of this crisis has been to force many countries to apply severe measures to reduce the impact on their financial services industry. Numerous banks and insurance company takeovers and capitalizations have taken place, the number of company mergers as a rescue measure has multiplied and crashes have increased. The full extent of this crisis is still unknown, since events have occurred at an unusually high speed, leading to enormous changes within a short time span, mainly following the crash of Lehman Brothers in September 2008.

The total number of banks operating in Spain at the time of the study was 110; of which 65 were commercial/retail banks and 45 were savings banks.

The small number of bodies comprising the banking industry in Spain could be an advantage or a disadvantage. On the one hand, the study can examine the whole population instead of a particular sample, but on the other hand, the small sample size can lead to problems in the analysis of data.

Only 85 out of the banks met the requirements of the study (i.e., banks serving the general public). Only 40 of the 65 commercial/retail banks qualified: of the remaining 25 banks, 17 simply bore a corporate name, but were the capital property of other banks, operating from within their offices; and eight were investment (not commercial) banks. Therefore, the target group consists of 85 financial bodies, representing around 77 percent of the total. 
The response rate was high, at around 90 percent, with 76 of the 85 banks completing the questionnaire by personal interview to the general manager in the main branch office. Of note is that all of the completed questionnaires were valid.

\section{Measures}

The authors of this paper measured all of the constructs in the questionnaires against existing scales in the literature and therefore all of the instruments in the study have a proven validity and reliability.

The model uses the Narver and Slater (1990) 15-item scale (the so-called MKTOR scale) to measure MO, which consists of three dimensions: customer orientation (CO), competitor orientation (COO) and interfunctional coordination (IC). With its emphasis on customer orientation, using the MKTOR scale is appropriate, given that the customer is the main object the study. Use of the MKTOR scale is also suitable because the study requires a strategic perspective and the cultural focus of this scale is more appropriate than the behavioral focus of Jaworski and Kohli's (1993) MARKOR scale. After cleaning the data, the scale included only 11 items (see Appendix 1).

The authors created their own scale to measure KM, taking items from several scales that previous investigations have used. From their literature review, the authors identified four key dimensions that affect KM processes: knowledge creation, knowledge transfer, knowledge application and knowledge storage/retrieval. The authors chose an absorptive capacity (AC) scale proposed by Jansen, Van den Bosch, and Volberda (2005) to measure knowledge creation, which adds to the conceptual richness of the study. The model uses Gold et al.'s (2001) scales to measure knowledge 
transfer (KT) and knowledge application (KA). To measure knowledge storage/retrieval, the authors used Chou et al.'s (2007) scale, which measures organizational memory $(\mathrm{OM})$. Organizational memory refers to the processing of saved knowledge, a concept which coincides with the authors' understanding of knowledge storage and retrieval. The final cleaned scale consists of 9 items for the creation dimension, 10 items for the transfer dimension, 10 items for the application dimension and 4 items for the storage/retrieval dimension (see Appendix 1).

The study uses Reinartz et al.'s (2004) scale to measure CRM, which measures the initiation (IN) and the maintenance and termination (MT) phases of the CRM processes, and which is very intuitive and easy to understand in practice. Due to the high number of items (the original scale consisted of 39 items), the scales only include items closest to the concepts, ideas and objectives of the study, giving a CRM scale consisting of 12 items ( 7 and 5 items, respectively). A group of experts, using a Delphi method, agreed that those 12 items are the most appropriate for the objectives of the study. At the end of this process, the final cleaned scale consists of 7 items (see Appendix 1).

In the case of the customer value creation capability, and after a review of the scales developed in previous investigations, the authors chose Hooley, Greenley, Cadogan, and Fahy's (2005) scale. The lack of proposals for measuring customer value creation created problems for the authors when seeking the most appropriate instrument for this construct. The model uses Hooley et al.'s (2005) scale because this scale is complete and refers to the creation of value for customers, as opposed to other proposals, which analyze value creation for all the stakeholders (see Appendix 1). 
Because the use of a single survey for data collection creates the potential for common-method bias, Podsakoff, MacKenzie, Lee, and Podsakoff (2003) recommend a number of steps to minimize that bias. Those authors recommend procedural remedies when including formative constructs. The procedural remedies applied are protecting respondent anonymity and reducing evaluation apprehension by ensuring subjects that right and wrong answers do not exist, improving scale items with the input of an expert panel and case study information, and counterbalancing question order. Otherwise, the authors of this paper tested for the presence of a potential mediation effect between some of the independent variables in the model. The existence of a mediation effect in this case is null.

\section{Data analysis}

In order to obtain a robust evaluation of the quality of the items, the authors carried out a confirmatory analysis (CFA), using the covariance matrix as input, via the EQS 6.1 robust maximum likelihood method (Bentler, 1988). As the model uses reflective and formative indicators and the data is non-normal, other software packages for structural equation modeling (e.g., LISREL or AMOS) were inappropriate (Diamantopoulos \& Winklhofer, 2001). The CFA produced a good fit with an incremental fit index (IFI) of 0.985 and a comparative fit index (CFI) of 0.984 (also, Satorra-Bentler $\left.\chi^{2}(38)=37.36 ; \chi^{2} / d . f=0.98 ; C F I=0.98 ; I F I=0.99 ; R M S E A=0.05\right)$.

In all the measurements, Bagozzi and Yi's (1988) composite reliability index and Fornell and Larcker's (1981) average variance extracted index was higher than the evaluation criteria of 0.7 for composite reliability and 0.5 for the average variance extracted. 
The authors determined the discriminant validity by calculating the shared variance between pairs of constructs (i.e., the lower triangle of the matrix in Table 1) and verifying that the value was lower than the average variances extracted for the individual construct (i.e., the diagonals in Table 1). The shared variances between pairs of all possible scale combinations indicate that the variances extracted are higher than the associated shared variances in all cases (Fornell \& Larcker, 1981). In the interest of thorough discriminant validity, the authors carried out an additional test, which supports this assumption, since the confidence interval ( \pm 2 standard errors) around the estimated correlation between any two latent indicators never includes 1.0 (Anderson \& Gerbing, 1988). Table 1 shows the shared variances, means and standard deviations.

\section{Table 1 here.}

\section{RESULTS}

After checking the psychometric properties of the measures, the next step was to evaluate the hypothesised relationships $-\mathrm{H}_{1 \mathrm{a}}, \mathrm{H}_{1 \mathrm{~b}}$ and $\mathrm{H}_{1 \mathrm{c}}-$ that the authors developed following a review of the relevant literature (see Figure 2). Table 2 shows the SEM results and that the fit of the model is satisfactory (Satorra-Bentler $\chi_{(62)}^{2}=85.12$; $\chi 2 / d . f=1.37 ; C F I=0.87 ; R M S E A=0.07)$, suggesting that the nomological network of relationships fits the data-another indicator that supports the validity of these scales (Churchill, 1979). With regard to the testing of hypothesis $\mathrm{H}_{1 \mathrm{a}}$, the results also support the significant effect of $\mathrm{KM}$ on MO, with a standardised coefficient of $0.95(p<0.001)$. These results also provide substantial support for $\mathrm{H}_{1 \mathrm{a}}(K M \rightarrow M O)$. In testing $\mathrm{H}_{1 \mathrm{~b}}$, Table 3 shows the significant effect of MO on CRM, with a standardised coefficient of 0.55 ( $p<0.001)$. For hypothesis $\mathrm{H}_{1 \mathrm{c}}$, Table 3 shows the significant effect of CRM on VC, with a standardised coefficient of 0.28 . 
Figure 2 here.

Table 2 shows that the goodness-of-fit measures are acceptable, although some are below the established values. The proposed model is therefore acceptable.

Table 2 here.

All of the results appear in Table 3.

Table 3 here.

\section{DISCUSSION}

The purpose of this study is to examine the relationship between MO, KM, CRM and the potential effects of these three capabilities in the customer value creation. In doing so, the authors propose a sequential model. As mentioned previously, this study does not confine itself to a proposal of the existence of a relationship between the interaction of the three capabilities and value creation, but rather, the aim is to identify what should be the relationship between the three organizational capabilities.

Model results confirm hypotheses $\mathrm{H}_{1 \mathrm{a}}, \mathrm{H}_{1 \mathrm{~b}}$ and $\mathrm{H}_{1 \mathrm{c}}$. As Table 3 shows, the results of the study confirm a strong and positive relationship between the three capabilities, and also confirm that $\mathrm{KM}$ is an antecedent of MO, which in turn precedes CRM.

First, the analysis provides support for hypothesis $1_{\mathrm{a}}$. As expected, KM has a significant positive effect on MO. Thus, once firms have the appropriate infrastructure to manage knowledge, they are prepared to generate, integrate and disseminate market information.

With regard to the testing of hypothesis 1 b, the results confirm that MO has a positive effect on CRM. The generation, integration and dissemination of market 
information lead firms to a more effective management of the relationships with their customers.

For hypothesis $1_{c}$, the findings demonstrate that CRM has a positive influence on customer value creation. Customers value the firm's activities oriented to the creation and maintenance of long-term relationships with them.

These findings confirm the important role of the three proposed organizational capabilities. KM and MO fosters CRM, which is essential for the creation of customer value. In fact, the data indicate that $\mathrm{KM}$ is a prior step to the creation of customer value. But KM does not have a direct influence on customer value creation. Then, KM has a positive influence on $\mathrm{MO}$ and $\mathrm{MO}$ has a positive influence on CRM, which finally impacts on customer value creation.

According to Eisenhardt and Martin (2000), the visible result of dynamic capabilities is the transformation of existing resources into new operational capabilities that are most appropriate for the environment. In this case, a recombination of the three capabilities creates a new capability with which firms can continue creating value for customers, regardless of changes in the environment. At this point, a value creation capability is the output of the MO, KM and CRM sequence.

Helfat and Peteraf (2003) state that DC does not directly affect the output of firms which possess these capabilities, but instead, makes an indirect contribution, through its impact on the firm's organizational capabilities. The results of this study verify that the sequence of the three organizational capabilities influences the creation of superior customer value and the processes involved in this sequence form the DC itself. The model therefore reflects this aspect. 
Drawing on the dynamic capabilities view is clearly appropriate for explaining the proposed relationship between the recombined organizational capabilities and superior customer value creation. Lepak, Smith, and Taylor (2007), in an analysis of the different sources of value creation, describe the possibility that firms can create value through DC. In fact, the proposed DC allows firms continually to reconfigure the goods and services value that they offer.

\section{CONCLUSIONS}

Over the past few years, customers have become the focus of attention; and every firm seeks to satisfy them in one way or another. Some firms orientate themselves to the market in order to create superior customer value through the culture and behaviors that this orientation promotes. Other firms prefer to manage their knowledge, while others focus on creating and maintaining long-term relationships with their customers.

Organizational capabilities are highly valuable attributes in a firm. Therefore, firms want to promote themselves as organizations that demonstrate a set of outstanding capabilities (Schreyögg \& Kliesch-Eberl, 2007). Firms will very often invest heavily in resources and capabilities, yet not enough in the capabilities they require to select, develop and deploy them efficiently (Maklan \& Knox, 2009). According to these authors, firms pay insufficient attention to developing the DC that they require to make these investments successful. A firm that possesses VRIN resources but does not use any DC, is unable to maintain its superior performance (Ambrosini \& Bowman, 2009). Firms' competitive advantage in the current environment does not originate simply from the distinctive resources and capabilities they possess, but also from the way that firms use these resources (Teece, 1998). 
DC is a relatively new subject in strategic management investigations, and therefore requires a great deal of analysis, particularly with regard to empirical studies. This paper responds to the demand for research within this knowledge area and the results of this study might also help firms to improve their current management style in order to create superior customer value.

The argument in this paper is that the three capabilities form a distinctive competence for firms and that by combining them a series of changes takes place which transform this distinctive competence into a DC for the firm. The high speed of change in the environment and the increasing strength of the competition highlight the fact that a firm's combinations of resources and capabilities must be difficult to imitate.

The authors of this study first try to show firms how they can create superior customer value by analyzing what happens inside the proposed "black box". This study assumes that firms possess the capabilities of MO, KM and CRM, each of which allows them to create value. A recombination of these capabilities will allow firms to create superior customer value or, at least, to maintain the value created in the current turbulent economic environment. Managers therefore must realize that although each of the three organizational capabilities is important in itself, they must link them all together if they are to create superior value. This might encourage managers to train all of their employees in each of the capabilities or to foster relationships between employees to encourage them to share the capabilities that each possesses. For example, training market oriented employees has little point if those employees then fail to manage their knowledge. Firm managers play a critical role in conveying to their employees the importance of having the three capabilities in place in order to create value. Therefore, unless managers send out clear signals to their employees regarding 
the importance of being oriented to the market and managing knowledge and customer relationships, firms will be unable to create superior customer value. For that to happen, managers have to be certain of the value of the three capabilities before they can communicate this belief to their employees.

Secondly, the authors' intention is for firm managers to use this study as a guide to improving customer value. Firms may already possess the capabilities they require to improve their competitive advantage but are not aware of this fact, or do not know how to achieve the desired result. As the reader will appreciate, the authors are not trying to establish a relationship between the recombined organizational capabilities and value creation; but rather, they examine the "black box" that this recombination comprises and suggest what the relationship between them should be. The sequence they propose, in which KM comes first, followed by MO and then CRM, allows managers to gain the maximum advantage from these capabilities to increase the value created for customers. This sequence helps to clarify the abstract idea of a recombination of the capabilities, which in turn helps firms to understand and adopt them. According to Cepeda and Vera (2007), researchers usually describe DC in abstract terms. In this study, the authors identify sets of activities (MO, KM and CRM) that might constitute a firm's DC, in an attempt to make the concept of DC more tangible. Establishing the definition of a DC that uses these activities could help firms to increase their knowledge of the mechanisms involved in the development and renewal of the firm's organizational capabilities.

The financial sector, and more specifically the banking industry, is undergoing radical changes, which are presenting banks with important challenges in how to overcome the crisis affecting the industry. In spite of the opportunities for the financial 
(and the banking) industry to implement strategic management based on MO, KM and $\mathrm{CRM}$, in reality, very few banks are willing to use their professional knowledge and tools. The results of this study should encourage firms to reconsider the management of their organizational capabilities, to take advantage of them and increase customer value creation.

The crisis in the industry has created an excellent opportunity for this study; that is, the circumstances of the financial environment (e.g., company mergers) are the ideal framework in which to reconfigure the organizational capabilities that a firm should possess in order to face the organizational and cultural changes brought about in the process of condensing several companies into one. Providing managers in the current economic situation with the tools and capabilities to foster MO, KM and CRM will help them to improve organizational effectiveness and efficiency. The development of DC proposed in this study can help the banks to maintain the capabilities which form the basis of their competitive advantage, and the authors propose that these capabilities are MO, KM and CRM.

Given that customer value is a dynamic construct, a major limitation of this study is that the data for the investigation derives from a single point in time. The study focuses on one particular industry (the Spanish banking industry), which prevents the generalization of the results to other economic areas. Furthermore, the model focuses on three capabilities that are the most important for customer value creation (MO, KM and CRM). The existing literature cites these organizational capabilities most often as being the ones with the greatest influence on customer value (McNaughton, Osborne, Morgan, \& Kutwaroo, 2001; Vorakulpipat \& Rezgui, 2008; Wang et al., 2004). The authors 
could of course find other capabilities to include in the model, and the explanatory power therefore only applies to the variables that they have considered in this study.

Finally, the state of the industry at the time of the study is very important. Although this situation created an ideal opportunity for study, problems arose when collecting data for the empirical investigation. Because of the high degree of turbulence in the industry at that time and the fact that the industry and its problems and uncertainties were under considerable discussion, some managers were wary of giving out data.

This investigation provides a springboard for future research into the maintenance or creation of customer value in the current environment, where competition is growing and the customer is becoming more demanding by the day. Possible future studies might extend the timescale and the scope of the study into other economic industries. Researchers would then be able to generalize the results and an extended model might include, for example, a firm's other capabilities that influence customer value creation. These might include, for example, a learning or ICT capability. 


\section{References}

Ambrosini V, Bowman C. What are dynamic capabilities and are they a useful construct in strategic management? International Journal of Management Reviews 2009;11(1):29-49.

Ambrosini V, Bowman C, Collier N. Dynamic capabilities: an exploration of how firms renew their resource base. British Journal of Management 2009;20:S9S24.

Amit R, Schoemaker, PJH. Strategic assets and organizational rent. Strategic Management Journal 1993;14(1):33-46.

Anderson JC, Gerbing DW. Structural equation modeling in practice: a review and recommended two-step approach. Psychological Bulletin 1988;103(3):411-23.

Bagozzi RP, Yi Y. On the evaluation of structural equation models. Journal of the Academy of Marketing Science 1988;16(1):74-94.

Baker WE, Sinkula JM. The synergistic effect of market orientation and learning orientation on organizational performance. Journal of the Academy of Marketing Science 1999;27(4):411-27.

Barney J. Firm resources and sustained competitive advantage. Journal of Management 1991;17(1):99-120.

Barney JB, Ketchen DJ, Wright M. The future of resource-based theory: revitalization or decline? Journal of Management 2011;37(5):1299-1315.

Barreto I. Dynamic capabilities: a review of past research and an agenda for the future. Journal of Management 2010;36(1):256-80.

Barroso C, Martín E. Marketing relacional. Madrid: ESIC Editorial; 1999. 
Bentler P. Practical issues in structural modeling. In: Long JS, editor. Common problems/proper solutions: avoiding error in quantitative research. Newbury Park, CA : Sage Publications; 1988. p. 161-92.

Boulding W, Staelin R, Ehret M, Johnston WJ. A customer relationship management roadmap: what is known, potential pitfalls, and where to go. Journal of Marketing 2005;69(4):155-66.

Cepeda G, Vera D. Dynamic capabilities and operational capabilities: a knowledge management perspective. Journal of Business Research 2007;60(5):426-37.

Chang T-Z, Chen S-J. Market orientation, service quality and business profitability: a conceptual model and empirical. Journal of Services Marketing 1998;12(6):24664.

Chen C-J; Huang J-W. Strategic human resource practices and innovation performance the mediating role of knowledge management capacity. Journal of Business Research 2009;62(1):104-14.

Chou T-C, Chang P-L, Cheng Y-P, Tsai C-T. A path model linking organizational knowledge attributes, information processing capabilities, and perceived usability. Information \& Management 2007;44(4):408-17.

Churchill GA. A paradigm for developing better measures of marketing constructs. Journal of Marketing Research 1979;16(1):64-73.

Cronin JJ, Brady MK, Hult GTM. Assessing the effects of quality, value, and customer satisfaction on consumer behavioral intentions in service environments. Journal of Retailing 2000;76(2):193-218.

Day GS. Market driven strategy: processes for creating value. New York: The Free Press; 1990. 
Day GS. The capabilities of market-driven organizations. Journal of Marketing 1994;58(4):37-52.

DeSarbo WS, Jedidi K, Sinha I. Customer value analysis in a heterogeneous market. Strategic Management Journal 2001;22(9):845-57.

Diamantopoulos A, Winklhofer H. Index construction with formative indicators: an alternative to scale development. Journal of Marketing Research 2001;38(2):269-77.

Easterby-Smith M, Prieto I. Dynamic capabilities and knowledge management: an integrative role for learning? British Journal of Management 2008;19(3):235-49.

Eisenhardt KM, Martin JA. Dynamic capabilities: what are they? Strategic Management Journal 2000;21(10/11):1105-21.

Fornell C, Larcker DF. Evaluating structural equation models with unobservable variables and measurement error. Journal of Marketing Research 1981;18(1):3950.

Gebert H, Geib M, Kolbe L, Brenner W. Knowledge-enabled customer relationship management: integrating customer relationship management and knowledge management concepts[1]. Journal of Knowledge Management 2003;7(5):10723.

Gold AH, Malhotra A, Segars AH. Knowledge management: an organizational capabilities perspective. Journal of Management Information Systems 2001;18(1):185-214.

Grant RM. Toward a knowledge-based theory of the firm. Strategic Management Journal 1996;17:109-22. 
Grewal R, Tansuhaj P. Building organizational capabilities for managing economic crisis: the role of market orientation and strategic flexibility. Journal of Marketing 2001;65(2):67-80.

Helfat CE, Peteraf MA. The dynamic resource-based view: capability lifecycles. Strategic Management Journal 2003;24(10):997-1010.

Holbrook MB. Customer value - a framework for analysis and research. Advances in Consumer Research 1996;23(1):138-42.

Hooley GJ, Greenley GE, Cadogan JW, Fahy J. The performance impact of marketing resources. Journal of Business Research 2005;58(1):18-27.

Huber GP. Organizational learning: the contributing processes and literatures. Organization Science 1991;2(1):88-115.

Hunt SD, Morgan RM. The comparative advantage theory of competition. Journal of Marketing 1995;59(2):1-15.

Ireland RD, Hitt MA, Sirmon DG. A model of strategic entrepreneurship: the construct and its dimensions. Journal of Management 2003;29(6):963-89.

Jansen JJP, Van den Bosch FAJ, Volberda HW. Managing potential and realized absorptive capacity: how do organizational antecedents matter? Academy of Management Journal 2005;48(6):999-1015.

Javalgi RG, Martin CL, Young RB. Marketing research, market orientation and customer relationship management: a framework and implications for service providers. Journal of Services Marketing 2006;20(1):12-23.

Jaworski BJ, Kohli AK. Market orientation: antecedents and consequences. Journal of Marketing 1993;57(3):53-70.

Kaplan RS, Norton DP. The strategy map: guide to aligning intangible Assets. Strategy \& Leadership 2004;32(5):10-17. 
Kaur G, Gupta MC. A perusal of extant literature on market orientation - concern for its implementation. Marketing Review 2010;10(1):87-105.

Kim H, Kim Y. A CRM performance measurement framework: its development process and application. Industrial Marketing Management 2009;38(4):477-89.

Kohli AK, Jaworski BJ. Market orientation: the construct, research propositions, and managerial implications. Journal of Marketing 1990;54(2):1-18.

Lafferty BA, Hult GTM. A synthesis of contemporary market orientation perspectives. European Journal of Marketing 2001;35(1/2):92-109.

Lee EJ, Overby JW. Creating value for online shoppers: implications for satisfaction and loyalty. Journal of Consumer Satisfaction, Dissatisfaction and Complaining Behavior 2004;17:54-67.

Lepak DP, Smith KG, Taylor S. Value creation and value capture: a multilevel perspective. Academy of Management Review 2007;32(1):180-94.

Li Y-H, Huang J-W, Tsai M-T. Entrepreneurial orientation and firm performance: the role of knowledge creation process. Industrial Marketing Management 2009;38(4):440-49.

Lin H-F. A stage model of knowledge management: an empirical investigation of process and effectiveness. Journal of Information Science 2007;33(6):643-59.

Liyun Q, Keyi W, Xiaoshu W, Fangfang Z. Research on the relationship among market orientation, customer relationship management, customer knowledge management and business performance. Management Science and Engineering $2008 ; 2(1): 31-37$.

Maklan S, Knox S. Dynamic capabilities: the missing link in CRM investments. European Journal of Marketing 2009;43(11/12):1392-1410. 
Maritan CA, Peteraf MA. Invited editorial: building a bridge between resource acquisition and resource accumulation. Journal of Management 2011;37(5):1374-89.

Martelo S, Barroso C, Cepeda G. Creating dynamic capabilities to increase customer value. Management Decision 2011;49(7):1141-59.

McNaughton RB, Osborne P, Morgan RE, Kutwaroo G. Market orientation and firm value. Journal of Marketing Management 2001;17(5/6):521-42.

Mizik N, Jacobson R. Trading off between value creation and value appropriation: the financial implications of shifts in strategic emphasis. Journal of Marketing 2003;67(1):63-76.

Mocciaro A, Battista G. The development of the resource-based firm between value appropriation and value creation. Advances in Strategic Management $2005 ; 22: 153-88$.

Morrow JL, Sirmon DG, Hitt MA, Holcomb TR. Creating value in the face of declining performance: firm strategies and organizational recovery. Strategic Management Journal 2007;28(3):271-83.

Narver JC, Slater SF. The effect of a market orientation on business profitability. Journal of Marketing 1990;54(4):20-35.

Newey LR, Zahra SA. The evolving firm: how dynamic and operating capabilities interact to enable entrepreneurship. British Journal of Management 2009;20:S81-S100.

Parasuraman A. Reflections on gaining competitive advantage through customer value. Journal of the Academy of Marketing Science 1997;25(2):154-61. 
Parasuraman A, Grewal D. Serving customers and consumers effectively in the twentyfirst century: a conceptual framework and overview. Journal of the Academy of Marketing Science 2000;28(1):9-16.

Payne A, Frow P. A strategic framework for customer relationship management. Journal of Marketing 2005;69(4):167-76.

Peppers D, Rogers M. Managing customer relationships. Hoboken, NJ: John Wiley \& Sons; 2004.

Peteraf MA, Barney JB. Unraveling the resource-based tangle. Managerial \& Decision Economics 2003;24(4):309-23.

Podsakoff PM, MacKenzie SB, Lee J-Y, Podsakoff NP. Common method biases in behavioral research: a critical review of the literature and recommended remedies. Journal of Applied Psychology 2003;88(5):879-903.

Porter ME. Competitive advantage - creating and sustaining superior performance. New York: Free Press; 1985.

Priem RL, Butler JE. Is the resource-based "view" a useful perspective for strategic management research? Academy of Management Review 2001;26(1),22-40.

Reinartz W, Krafft M, Hoyer WD. The customer relationship management process: its measurement and impact on performance. Journal of Marketing Research 2004;41(3):293-305.

Rogers M. Customer strategy: observations from the trenches. Journal of Marketing 2005;69(4):262-63.

Sánchez R, Iniesta MA. Consumer perception of value: literature review and a new conceptual framework. Journal of Consumer Satisfaction, Dissatisfaction and Complaining Behavior 2006;19:40-48. 
Sánchez R, Iniesta MA, Holbrook MB. The conceptualisation and measurement of consumer value in services. International Journal of Market Research 2009;51(1):93-113.

Schreyögg G, Kliesch-Eberl M. How dynamic can organizational capabilities be? Towards a dual-process model of capability dynamization. Strategic Management Journal 2007;28(9):913-33.

Schumpeter J. The theory of economic development. Cambridge, MA: Harvard University Press; 1934.

Sin LYM, Tse ACB, Yim FHK. CRM: conceptualization and scale development. European Journal of Marketing 2005;39(11/12):1264-90.

Sinkula JM, Baker WE, Noordewier T. A framework for market-based organizational learning: linking values, knowledge, and behavior. Journal of the Academy of Marketing Science 1997;25(4):305-18.

Sirmon DG, Hitt MA. Managing resources: linking unique resources, management, and wealth creation in family firms. Entrepreneurship: Theory \& Practice 2003;27(4):339-58.

Sirmon DG, Hitt MA, Ireland RD. Managing firm resources in dynamic environments to create value: looking inside the black box. Academy of Management Review 2007;32(1):273-92.

Slater SF, Narver JC. Market orientation and the learning organization. Journal of Marketing 1995;59(3):63-74.

Slater SF, Narver JC. Customer-led and market-oriented: let's not confuse the two. Strategic Management Journal 1998;19(10):1001-06.

Smith JB, Colgate M. Customer value creation: a practical framework. Journal of Marketing Theory \& Practice 2007;15(1):7-23. 
Spiteri JM, Dion PA. Customer value, overall satisfaction, end-user loyalty, and market performance in detail intensive industries. Industrial Marketing Management 2004;33(8):675-87.

Teece DJ. Capturing value from knowledge assets: the new economy, markets for know-how, and intagible assets. California Management Review 1998;40(3):5579.

Teece DJ, Pisano G, Shuen A. Dynamic capabilities and strategic management. Strategic Management Journal 1997;18(7):509-33.

Tsai M-T, Li Y-H. Knowledge creation process in new venture strategy and performance. Journal of Business Research 2007;60(4):371-81.

Tuominen M, Rajala A, Möller K. Market-driving versus market-driven: divergent roles of market orientation in business relationships. Industrial Marketing Management 2004;33(3):207-17.

Vorakulpipat C, Rezgui Y. Value creation: the future of knowledge management. The Knowledge Engineering Review 2008;23(3):283-94.

Wang CL, Ahmed PK. Dynamic capabilities: a review and research agenda. International Journal of Management Reviews 2007;9(1):31-51.

Wang Y, Lo HP, Chi R, Yang Y. An integrated framework for customer value and customer-relationship-management performance: a customer-based perspective from China. Managing Service Quality 2004;14(2/3):169-82.

Winter SG. Understanding dynamic capabilities. Strategic Management Journal 2003;24(10):991-95.

Woodruff RB. Customer value: the next source for competitive advantage. Journal of the Academy of Marketing Science 1997;25(2):139-53. 
Yim FH-k, Anderson RE, Swaminathan S. Customer relationship management: its dimensions and effect on customer outcomes. Journal of Personal Selling \& Sales Management 2004;24(4):263-78.

Zablah AR, Bellenger DN, Johnston WJ. An evaluation of divergent perspectives on customer relationship management: towards a common understanding of an emerging phenomenon. Industrial Marketing Management 2004;33(6):475-89.

Zahra SA, Sapienza HJ, Davidsson P. Entrepreneurship and dynamic capabilities: a review, model and research agenda. Journal of Management Studies 2006;43(4):917-55.

Zott C. Dynamic capabilities and the emergence of intraindustry differential firm performance: insights from a simulation study. Strategic Management Journal 2003;24(2):97-125. 


\section{Appendix 1. Questionnaire Items}

\section{Customer Orientation ( $1=$ not at all and $7=$ always):}

CO_1: We monitor our level of commitment and our orientation towards serving customers' needs

CO_2: Our business strategies are driven by our beliefs about how we can create greater value for customers

CO_3: Our strategy for competitive advantage is based on our understanding of customer needs

CO_4: We pay close attention to after-sales service

\section{Competitor Orientation ( $1=$ not at all and $7=$ always):}

COO_1: Our salespeople share information within our business concerning our competitors' strategies

COO_2: We respond to competitive actions that threaten us

COO_3: The management team regularly discusses our competitors' strengths and strategies

Interfunctional Coordination ( $1=$ not at all and $7=$ always):

IC_1: Managers from each department have information about our current and prospective customers

IC_2: We communicate information about our successful and unsuccessful customer experiences across all business areas

IC_3: All of our business areas are integrated into serving the needs of our target markets

IC_4: Managers understand how everyone in our company can contribute to creating customer value

\section{Knowledge Creation (1= strongly disagree and $7=$ strongly agree).}

AC_1: Our unit has frequent interaction with corporate headquarters to acquire new knowledge

AC_2: We collect industry information through informal means (e.g., lunch with industry friends, talks with trade partners)

AC_3: Our unit periodically organizes special meetings with customers or third parties to acquire new knowledge

AC_4: We are slow to recognize shifts in our market (e.g., competition, regulation, demography) (reverse-coded)

AC_5: New opportunities to serve our clients are quickly understood

AC_6: We quickly analyze and interpret changing market demands

AC_7: It is clearly understood how activities within our unit should be performed

AC_8:We constantly consider how better to exploit knowledge

AC_9: Our unit has difficulty developing new services (reverse-coded)

Knowledge Transfer (1 = strongly disagree and 7= strongly agree).

KT_1: My organization has processes for converting knowledge into the design of new services

KT_2: My organization has processes for converting competitive intelligence into plans of action

KT_3: My organization has processes for filtering knowledge

KT_4: My organization has processes for transferring organizational knowledge to individuals

KT_5: My organization has processes for absorbing knowledge from individuals into the organization

KT_6: My organization has processes for absorbing knowledge from business partners into the organization

KT_7: My organization has processes for distributing knowledge throughout the organization

KT_8: My organization has processes for integrating different sources and types of knowledge

KT_9: My organization has processes for organizing knowledge

KT_10: My organization has processes for replacing outdated knowledge

Knowledge Application (1 = strongly disagree and 7= strongly agree).

KA_1: My organization has processes for applying knowledge learned from mistakes

KA_2: My organization has processes for applying knowledge learned from experience

KA_3: My organization has processes for using knowledge in the development of new services

KA_4: My organization has processes for using knowledge to solve problems

KA_5: My organization matches sources of knowledge to problems and challenges

KA_6: My organization uses knowledge to improve efficiency

KA_7: My organization uses knowledge to adjust strategic direction

KA_8: My organization makes knowledge accessible to those who need it

KA_9: My organization takes advantage of new knowledge

KA_10: My organization applies knowledge to critical competitive needs 


\begin{tabular}{|l|}
\hline Knowledge Storage and Retrieval (1= strongly disagree and 7= strongly agree). \\
\hline OM_1: Organizational conversation keeps the lessons learned from service development history at the front of our \\
minds \\
OM_2: We always audit unsuccessful service development endeavours and communicate the lessons learned \\
OM_3: We have specific mechanisms for sharing lessons learned in the service development process \\
OM_4: Formal routines exist to uncover faulty assumptions about the service development process \\
\hline CRM Initiation (1= strongly disagree and 7= strongly agree). \\
\hline IN_1: We have a formal system in place that facilitates the continuous evaluation of prospects \\
IN_2: We have a system in place to determine the cost of re-establishing a relationship with a lost customer \\
IN_3: We have a systematic process for assessing the value of past customers with whom we no longer have a \\
relationship \\
IN_4: We have a system for determining the costs of re-establishing a relationship with inactive customers \\
\hline CRM Maintenance and Termination (1= strongly disagree and 7= strongly agree). \\
\hline MT_1: We have a formal system for determining which of our current customers are of the highest value \\
MT_2: We continuously track customer information in order to assess customer value \\
MT_3: We have a formal system for identifying non-profitable or lower-value customers \\
\hline Customer Value Creation (1= much lower and 7= much higher). \\
\hline CV_1: Levels of customer loyalty compared to competitors \\
CV_2: Levels of customer satisfaction compared to last year \\
CV_3: Levels of customer loyalty compared to last year
\end{tabular}

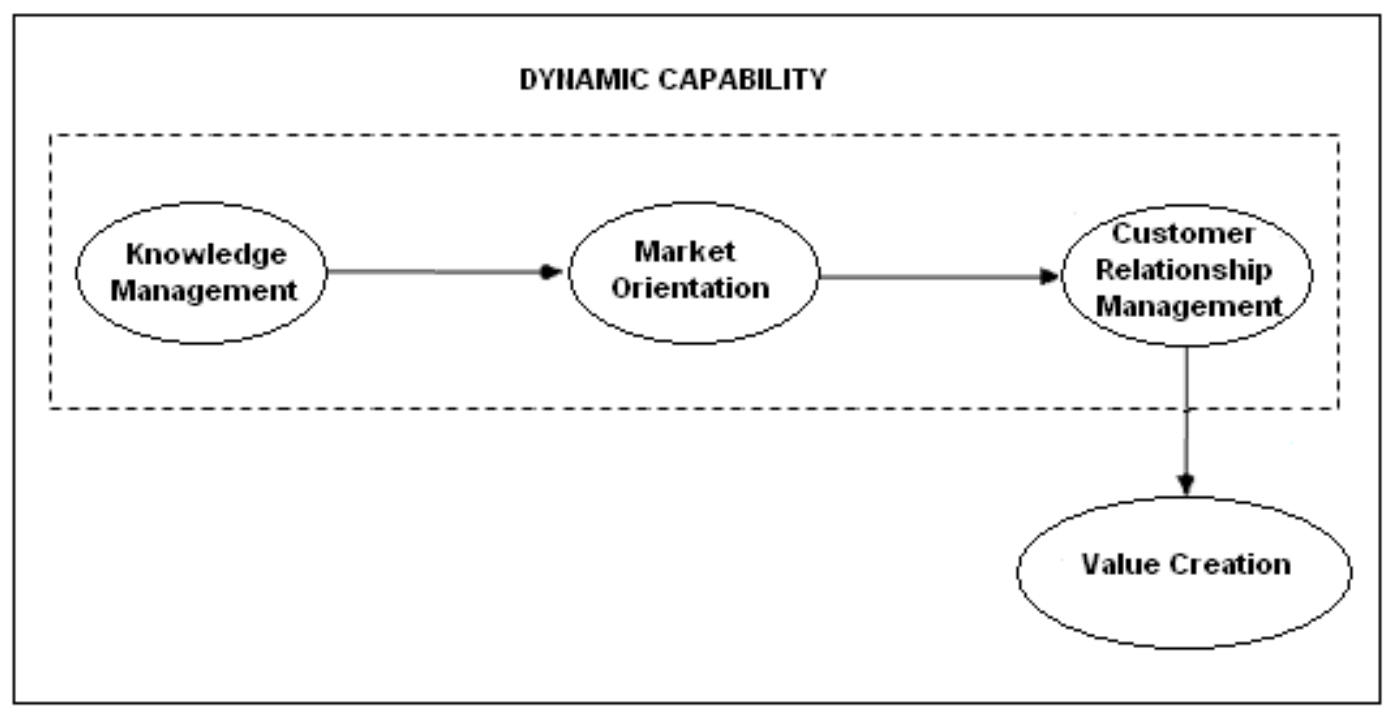

Figure 1

Conceptual Model 


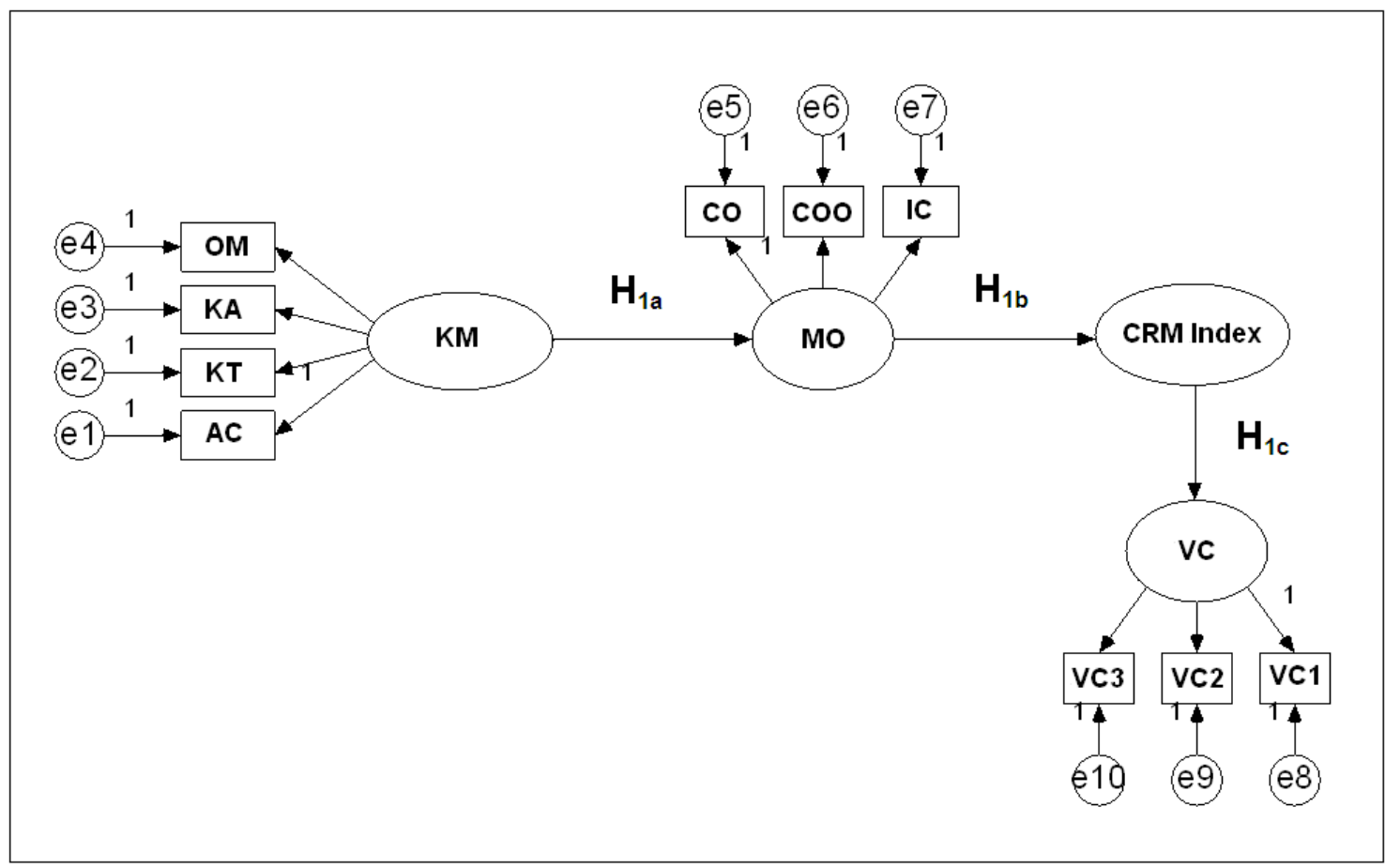

Figure 2

Research Model

Table 1. Descriptive Statistics and Discriminant Validity

\begin{tabular}{|c|c|c|c|c|c|c|c|c|}
\hline & Mean & SD & AVE & CR & 1 & 2 & 3 & 4 \\
\hline 1. Market Orientation & 5.5 & 0.9 & 0.65 & 0.88 & 0.81 & & & \\
\hline 2. Knowledge Management & 5.3 & 0.9 & 0.8 & 0.88 & 0.80 & 0.89 & & \\
\hline 3. Customer Relationship Management & 5.5 & 1.3 & n.a & n.a & 0.51 & 0.46 & n.a & \\
\hline 4. Customer value creation & 5.3 & 1.2 & 0.63 & 0.82 & 0.29 & 0.42 & 0.23 & 0.79 \\
\hline
\end{tabular}

Notes:

Mean = the average score for all of the items included in this measure; SD = Standard Deviation; AVE = Average Variance Extracted; the bold numbers on the diagonal are the square root of the Average Variance Extracted, Shared Variances are given in the lower triangle of the matrix; $\mathrm{CR}=$ Composite Reliability. 
Table 2. Goodness-of-fit Measures Model

\begin{tabular}{|l|r|}
\hline & \multicolumn{1}{|c|}{ Model } \\
\hline Degree of freedom & 62 \\
\hline Satorra-Bentler & $85.12(\mathrm{p}=0.03)$ \\
\hline Goodness-of-fit-Index (GFI) & 0.86 \\
\hline Root Mean Square Residual (RMSR) & 0.12 \\
\hline Root Mean Square Error of Approximation (RMSEA) & 0.07 \\
\hline Adjusted Goodness-of-fit Index (AGFI) & 0.80 \\
\cline { 1 - 1 } Normed Fit Index (NFI) & 0.88 \\
\hline Comparative Fix Index (CFI) & 0.87 \\
\hline
\end{tabular}

Table 3. Summary of Results

\begin{tabular}{|l|c|c|c|c|}
\hline \multicolumn{1}{|c|}{ Model } & Hypotheses & $\begin{array}{c}\text { Supported/Non } \\
\text { supported }\end{array}$ & $\begin{array}{c}\text { Standardized } \\
\text { parameter } \\
\text { estimate }\end{array}$ & $\mathrm{R}^{2}$ \\
\hline $\mathrm{KM}------>\mathrm{MO}$ & $\mathrm{H}_{1 \mathrm{a}}$ & Yes & $0.95^{\star \star \star}$ & 0.90 \\
\hline $\mathrm{MO}----->\mathrm{CRM}$ Index & $\mathrm{H}_{1 \mathrm{~b}}$ & Yes & $0.55^{\star \star \star}$ & 0.30 \\
\hline $\mathrm{CRM}$ Index----->VC & $\mathrm{H}_{1 \mathrm{c}}$ & Yes & $0.28^{\star *}$ & 0.08 \\
\hline
\end{tabular}

